\title{
DRAUGHT ANIMAL POWER UTILIZATION ON SMALLHOLDER FARMS IN KADUNA STATE, NIGERIA
}

\author{
J.O. GEFU; A.H. NDUBUISI and E.O. OTCHERE, \\ Livestock Systems Research Programme, National Animal Production Reseanch Institite, \\ Ahmadu Bello University, P.M.B. 1096, Zaria.
}

Received 22 April, 1994; Accepted 10 June, 1995

\begin{abstract}
A survey on draught animal power (DAP) use on small holder farms in Giwa Local Government Area of Kaduria State was conducted during the 1988/89 farming season. A purposive sampling technique was utilized where all the 25 household heads who owned and used draught animals were sample. Structured questionnaire schedule was developed and used for data collection. The findings revealed that maijority ( $88 \%)$ of the respondents were between the 20 and 29 years of age. While majority $(92 \%)$ of the respondents started with a pair of work animals, only $4 \%$ started with two pairs. White Fulani (Bunaji) cattle was the popular breed among the respondents. The animal were used for achieving three different agricultural tasks. The constraints associated with animal power utilization include unavailability and high cost of implements, scarcity of feed during the dry season and animal disease.
\end{abstract}

Key words: Draught animal, Bunaji, small holder

\section{INTRODUCTION}

Attempts by Nigerian Government to boost agricultural production through the pursuance of aggressive tractorization policy have not yielded much fruits. Ox-powered mechanization has been shown to be superior in terms of return to land, labour and capital than both manual cultivation and tractor powered mechanization which is currently in disarray in Nigeria (Bceney, 1975). The highly successful oxenization programme which contributed significantly to the expansion of cotton and cereal production in Burkina Faso is a case in reference. The use of cattle for cultivation was introduced into Nigeria as early as 1922. By 1939, there were about 1959 farmers who owned work oxen while by 1965 , the number of farmers had increased to 36,000
(Alkali, 1969). It has been observed that up to date, estimates of work oxen population in Nigeria is lacking. However, work-bulls can be estimated to constitute about 10 per cent of the national cattle population (Gefu and Otchere, 1991).

The development of Nigeria's agricultural sector depends largely on the productivity of the numcrous rural-based small-scale farmers who either utilize simple hand tools and/or animal drawn implements. It is this sector of the population that provides much of the staple food consumed in the country especially food grains in the savanna regions. The need to increase the level of production of traditional staple food crops especially in the Savanna areas of the country cannot be over emphasized. This is even moreso with the present population growth, rapid urbanization and rural depopulation which have caused the demand for marketed food stuffs to outrun domestic production capacity (Berry, 1984).

Furthermore, the recent phenomenal increase in the price of tractors, implements and spare parts in many developing countries coupled with deteriorating foreign exchange rate makes tractor ownership or hiring virtually beyond the reach of small holder farmers. The overall importance of tractor farming has virtually declined. Oxen are important suppliers of draught power for land development, tillage, threshing and transportation in many developing countries. The use of bullocks as animal power on farms is widespread in most areas of Nigeria's savanna.

The advantage of animal traction is its relatively low cost and availability at time of need, thus enabling its adoption by the majority of farmers with limited financial resources. The use of animal traction is an 
appropriate technology which will not only ameliorate the food crisis by boosting production but will also conserve foreign exchange and pave way to domestic industrial growth through small-scale manifacturing of implements. The integration of crop and livestock production will also be encouraged.

Thus, an in-depth evaluation of animal traction as a major source of power in the agricultural sector of the Nigerian economy is required. Despite the long history of animal traction in Nigeria, there is a dearth of literature especially on the socio- economic dimension.

\section{METHODOLOGY}

Data were collected through the use of structured questionnaire from 25 household heads who owned and used work animals in Giwa Local Government Area of Kaduna State, Nigeria. The respondents were the collaborating famers of the Livestock Systems Research Programme (LSRP) at the National Animal Production Research Institute (NAPRI), Zaria. Four trained livestock enumerators collected data on behalf of the researchers. Data were analysed through the use of percentages.

The primary focus of the study was to describe the structure and constraint of draught animal power utilization. Specifically the study was designed to: Ascertain the socioeconomic characteristics of the respondents; Identify the animal work period; Ascertain the animals' agricultural tasks and Identify the constraints associated with draught animal power utilization

\section{RESULTS AND DISCUSSION}

\section{Socioeconomic and personal characteristics}

Age:

About $52 \%$ of the respondents were between 30 and 39 years of age. Majority $(88 \%)$ of the respondents were between 20 and 49 years. Only $12 \%$ were 50 years and above. The average age of the farmers was 33.48 years. This implies that majority of the farmers can act as innovators in the adoption of any intervention to the improvement of DAP usage (Alao, 1971).

\section{Length of Stay in the study area:}

About $76 \%$ of the respondents indicated that they have been resident in the study area for more than 20 years. Four per cent of the respondents have been resident in the area for only $1-5$ years.

\section{Household size:}

Average household consisted of seven persons. This suggests that majority of the farmers have no intention of leaving the study area having lived so long there.

\section{Use of DAP}

About $48 \%$ of the farmers have used DAO for five years while $36 \%$ have up to 10 years experience using DAP. About ninety-two per cent started with a pair of animals while only four per cent started with two pairs. This has implications for credit availability to the farmers to enable them acquire work-bulls. The average farm size was 5.88 ha.

\section{Choice of animal breed:}

All respondents indicated that they used Bunaji (White Fulani) cattle. This breed of cattle (Bos indicus) is predominant in northern Nigeria. In an earlier study, Otchere et wi. (1988) reported that the choice of this breed was due to its ability to work, availability and docility.

Other users of the animals and work schedules

About $76 \%$ of the respondents indicated that they rented out their work-bulls to a total of about 229 people. On the average they covered about 6 hectares of farm land. This practice of renting yielded an average sum of A1284.20 the work-bull owners. Ridging and re-ridging were the major tasks for which work bulls were used.

Bolaji (1990) reported that animals were usually worked from $6.00 \mathrm{a} . \mathrm{m}$. to $11.00 \mathrm{a} . \mathrm{m}$. and from 3.00 p.m. to 6.00 p.m. with a resting period of three hours during which they are allowed to graze on forage. Table 1 shows work period of the animals in the study area. 


\section{DRAUGHT ANIMAL POWER}

The average lifespan of a pair of animals was 6.6 years, after which animals were sold off and replaced by younger pairs.

The major operations the draught animals are engaged in are presented in Table 2. Majority (88\%) of the respondents used draught animal power for ridging earthing-up and re-ridging. While $4 \%$ used the work animals for ridging and weeding, $8 \%$. used the animals for both ridging and harrowing. This limited use of DAP for farm operations may have emanated from the fact that there are limited implements for use in most of the farm operations.

\section{Limitations to draught animal use}

\section{Finance:}

A pair of bulls without implements was estimated to cost approximately $\$ 3000.00$ at the time of the study. Today, the same pair of bulls will cost between $\mathrm{N10,000}$ and $\mathrm{N14,000}$. Moreover, the cost of an animal drawn implement (a ridger, for example) at about N4,500 cannot be easily affordeci by the farmer. This makes it difficult for the farmers in the area to purchase the workbulls and the implements since their average annual income is less than $N 1,000$. All respondents mentioned finance as a major constraint in effectively utilizing draught animals.

\section{Nutrition}

Draught animals, like other farm animals, have nutritional requirements for water and feed. The level of water and feed required by the animal vary according to body size, age, amount of work load and the productive stage the aninals as well as the speed and the productive stage of the animal. Alhassan (1990), citing Hrabovsky (1983) stated that draught animals require 30\% extra feed in order to perform work tasks.

Most animals for $\mathrm{DA} P$ in Nigeria are fed largely on poor crop residues in the dry season and graze native forage in the wet season. The crop residues are known to be low in nitrogen and high in cell wall. These lead to decreased digestibility and voluntary feed intake while critical nutrients must be supplied in a supplement. Poor nutrition has often resulted in poor condition of these animals resulting in poor performance at the time they are most required for serious farm operations. To buttress the importance of adequate feeding during the dry months of the year, an average of $N 856.08$ was spent on the purchase of feed materials during the dry season of 1989. Majority $(95.65 \%)$ of the respondents mentioned dry season feeding was a major problem.

\section{Health}

Table 3 presents the disease constraints of draught animals. Diseases also limit the optimal use of draught animals. This is especially true of chronic diseases that result in weakness, emaciation and eventual death of the animals. An average of $\$ 531.36$ was reported to have been spent on veterinary care for a pair of work-bulls during the study period. Some of the diseases of economic importance to drught animals in the study area include Dermatophilosis (Kirchi), Liver fluke (Hanta/jini), Ectoparasites such as lice, flees and ticks, Contagious Bovine Pleuropneumonia (Huhu), and Trypanosomiasis (Samore). Control of some of the disease, especially ecto- and endoparasites, could be achieved by spraying, deworming and other prophylactic treatments.

\section{Implements:}

The problems associated with implements as indicated by the respondents are presented in Table 4. About $42 \%$ of the respondent said that their greatest problem was in relation to the extension beam while $31.58 \%$ said that their problem laid mostly with Blade/wing. Similarly, $21.05 \%$ of the respondents complained that the implements wear out fast while only $5.26 \%$ indicated that the implements were not readily available.

As a result, the famers have often relied on the local blacksmiths to re-fabricate the implement, especially the sheer, for durability and effective tillage. Experience has shown that local blacksmiths can fabricate a ridger comparable to factory- produced ridgers with longer life span and more efficiency in tilling the soil. The blacksmiths can nevertheless be 
J.O. GEFU ET AL

TABLE 1: DISTRIBUTION OF RESPONDENTS BY ANIMAL WORK PER:ODS

\begin{tabular}{lll}
\hline Period & F & \% \\
\hline Morning only & 12 & 48 \\
Morning/Evening & 13 & 52 \\
\hline Total & 25 & 100 \\
\hline
\end{tabular}

Source: Field Survey $1988 / 89$

TABLE 2: DISTRIBUTION OF RESPONDENTS BY ANIMAL"S TASKS

\begin{tabular}{llc}
\hline Task & F & $\%$ \\
\hline Ridging + earthing-up & 22 & 88 \\
Ridging + Wecding & $1 \cdot$ & 4 \\
Ridging + Harrowing & 2 & 8 \\
\hline Total & 25 & 100 \\
\hline
\end{tabular}

TABLE 3: DISEASE CONSTRAINTS TO DRAUGHT ANIMAL POWER

\begin{tabular}{lll}
\hline Disease type & F & $\%$ \\
\hline Kirchi (Dermatophilosis) & 3 & 13.04 \\
Hanta/jini (Liver fluke) & 9 & 39.13 \\
Huhu (Contagious Bovine & & \\
Pleuropneumonia - CBPP) & 6 & 26.09 \\
Samore (Trypanosomiasis) & 2 & 8.70 \\
Fatigue & 2 & 8.70 \\
Other Ectoparasites & 1 & 4.35 \\
\hline Total & 23 & 100.00 \\
\hline
\end{tabular}

TABLE 4: PERCENTAGE DISTRIBUTION OF RESPONDENTS ON THE BASIS OF PROBLEMS ASSOCIATED WITH THE IMPLEMENTS.

\begin{tabular}{lll}
\hline Problem & F & $\%$ \\
\hline Not readily available & 1 & 5.26 \\
Blade/wing & 6 & 31.58 \\
Extension bean & 8 & 42.11 \\
Wears out fast & 4 & 21.05 \\
\hline Total & 19 & 100.00 \\
\hline
\end{tabular}


relied upon for the production of spare parts if encouraged. The government is therefore urged to help these local backsmiths to engage in the mass production of implements at affordable prices by the small-scale farmers.

\section{CONCLUSIONS AND RECOMMENDATIONS}

There is a possibility of relative expansion of DAP use in northern Nigeria. However, for this to be realized, certain constraints must be addressed. The most important ones relate to the availability of traction implements, their costs and maintenance, disease outbreak, etc. Also, most post-ridging operations are still not adaptable to the use of DAP, and are still done by hand.

Based on the findings of this study, the following recommendations are drawn:

1. Veterinary services and supplies for draught animals should be made available to the work bull owners at reasonable prices.

2. Adequate incentives should be given for the local fabrication of DAP implements by the local balcksmiths for on-and off-farm tasks. This will not only make animal drawn implements readily available at reasonable prices, but will also provide employment opportunties for the local artisans such as blacksmiths and others engaged in retailing their products.

3. Credit facilities should be provided at reasonable rates for the individual farmers or farmer groups for the purchase and maintenance of draught animals and traction implements.

4. Financial support for research into the development of better breeds of work animals should be undertaken by the government and private organization.

\section{REFERENCES}

ALAO, J.A. (1971). Commurity structure and modernization of Arriculture An enalysis of fectors influencing the edoption of bur practices among Nigerian farmers. Unpublished M.D. Divertation, Cornell Univerrity, Ithace, New Yort.

ALHASSAN, W.S.(1990), "Feed requirements for draught animals in Nigeria", In: Gefu, J.O. and Otchere, EO. (eds.) Draught animal power research and development in Nigeria. Proceedings of the first national workshop on animal traction in Nigeria held at NAPRI, ABU, Shika, Zaria, Nigeria, June 1989. Pp. 121-132.

ALKALI, M. (1969). Mixed farming; need and potential. In Livestock developmet in the dry and intermediate savanna zones. Proceedings of a conference held at ABU, Zaria, 16-18 June.

BEENEY, J.M. (1975). "Socio-economic factors associated with draught animal power utilization in Nigeria". In: Gefu, J.O. and Otchere, E.O. (eds.). Draught animal power research and development in Nigeria. Proceedings of the first national workshop on animal traction in Nigeria held at NAPRI., ABU, Shika, Zaria. Nigeria, June $1989 . \quad$ P. 10-16.

BOLAJI, A. (1990). "Socio-economic factors associated with draught animal power utilization in Nigeria". In:Gefu, J.O. and Otchere, E.O. (ads.). Draught animal power research and development in Nigeria. Procecdings of the first national workshop on animal traction in Nigeria held at NAPRJ, ABU, Shika, Zaria, Nigeria, June 1989. Pp. 10-16.

GEFU, J.O. and OTCHERE, E,O. (1991). Draught animals in Nigeria: availability, use and problems. Paper presented at the northwest generalized in-service training for agricultural field workers organised by the NAERLS, ABU, Zaria, 24 - 28 Junc. 13 pp.

OTCHERE, E.O.; AHMED H.U; OLORUNUU, S.A.S. and KALLAH, M.S. (1988). "Utilization and management of work oxen in a Guinea savanna environment in Nigeria: Initial surveys", In: Starkey, P. and Ndiame, F. (eds). Aniunal power in farming sysiem. Proceedings of the second West African Animal Traction Networkshop held Sept. 19 - 25, 1986, Freetown, Sierra Leone. Pp. 233-237.

PHILIP, D.O.A.; ABALU G.O.I; AGANGA, A.A. and ADUKU, A.O. (1990). "Animal traction technology in northern Nigeria: Starkey P. and Faye, A. (eds.). Animal traction for agriculturwl development. Proceedings of the third workshop of the West African Animal Traction Network held 7-12 July, 1988, Saly Senegal. Pp. 370-375. 